\title{
Annelerin Bebeklik Döneminde Gelişime İlişkin Bilgi ve Kaygı Düzeylerinin Değerlendirilmesi
}

\author{
Assessment of Mothers' Knowledge and Anxiety Levels About \\ Developmenta At Infancy
}

\author{
Alev ŞAHINÖZ',Aynur BÜTÜN AYHAN²
}

${ }^{1}$ Sağlık Bilimleri Üniversitesi, Ankara Çocuk sağlığı ve Hastalıkları Hematoloji Onkoloji SUAM, Çocuk Gelişim Bölümü, ANKARA

${ }^{2}$ Ankara Üniversitesi, Sağlık Bilimleri Fakültesi, Çocuk Gelişimi Anabilim Dalı, ANKARA

\section{Öz}

Amaç: Ilk iki yaşta bebeği olan annelerin bebeklik döneminde gelişime ilişkin bilgi ve kaygı düzeylerinin çeșitli değişkenler açısından incelenmesi amacıyla bu araştırma planlanmıştır.

Gereç ve Yöntemler: Araştırma, Ankara il merkezinde bulunan Sağlık Bakanlığı' na bağlı çocuk hastanesinin sağlam çocuk polikliniğine başvuran, çalışmaya katılmayı kabul eden ve doğum haftası en az 37 hafta ve yașları 0-24 ay arasında olan bebeğe sahip toplam 102 anne ile gerçekleștirilmiştir. Araşıtımada veri toplama aracı olarak, "Aile Bilgi Formu", "Annelerin Bebeklik ve Erken Çocukluk Dönemi Gelișimi ve Gelişimin Desteklenmesi Bilgisi Ölçeği (Gelișim Bilgisi Ölçeği) ve Sürekli Kaygı Ölçeği (Kaygı Ölçeği) kullanılmıștır. Verilerin analizinde frekans, ortalama, standart sapma, tek yönlü varyans analizi (ANOVA), t-testi ve Tukey çoklu karşılaşııma testi kullanılmışıı.

Bulgular: Gelișim Bilgisi Ölçeği’ ne göre annelerin \% 63.7'si çocuklarıın gelişimleri ile ilgili yeterli bilgiye sahip olmadığını ifade etmiş̧ir. Araştırmaya katılan annelerin \% 62.7'si çocuk gelişimi ile ilgili kitap/dergi/broşür gibi yazlı materyal okuduğunu belirtmiştir. Çocuk gelișimine yönelik herhangi bir yazılı materyal okuyan annelerin çocuk gelişimi bilgi düzeyinin okumayanlara oranla yüksek olduğu bulunmuştur. Çocuk Gelişimci ile görüşen annelerin Gelişim Bilgisi Ölçeği puan ortalamaları, görüşmeyen annelerin puan ortalamalarına göre anlamlı düzeyde yüksek olduğu belirlenmiştir. Çocuk gelişimi ile ilgili bilgi düzeyi yüksek olan annelerin kaygı düzeylerinin de düşük olduğu belirlenmiştir.

Sonuç: Araştırmadan elde edilen bulgulara göre annelerin çocuk gelișimi ile ilgili bilgi düzeyini artıracak çalısmalar planlanması, eğitim programları hazırlanması ve bu programların yaygınlaştıııması, ailelerin bilgi düzeyini artıracak uzman kadronun sayıca artırıması gerekmektedir.

Anahtar Sözcükler: Kaygı, Bebeklik dönemi, Çocuk gelişimi, Anne bilgisi

\begin{abstract}
Objective: The study has been conducted to examine anxiety and knowledge levels of mothers whose infants aged 0-24 months regarding development at infancy according to some variables.

Material and Methods: The study was conducted with 102 mothers whose infants aged 0-24 months and their gestational week was at least 37, who were consulted at a Hospital's Child Health Surveillance Clinic and agreed to participate in the research. Mothers completed the "Family Information Form", "The Caregiver Knowledge of Child Development Inventory (CKCDI)", "Trait Anxiety Scale" which is part of "State and Trait Anxiety Scale". In order to analyze variables, "Shapiro-Wilk", "ANOVA", "t-test" and "Tukey's test" were used.

Results: Of $63.7 \%$ mothers stated that they do not have enough knowledge about their children's development and $62.7 \%$ of all mothers also mentioned that they read written materials such as book/magazine/booklet about child development. It is found that mothers who read written materials have more knowledge about child development in comparison with mothers who do not read. Also, mothers who have more knowledge about child development had lower anxiety level.
\end{abstract}

(1) ȘAHINÖZ A : 0000-0002-2225-5704 BÜTÜN AYHAN A : 0000-0003-3306-9672
Çıkar Çatışması / Conflict of Interest: On behalf of all authors, the corresponding author states that there is no conflict of interest.

Etik Kurul Onay / Ethics Committee Approval : Bu çalıșma için Ankara Çocuk Sağlğ̆ı ve Hastallkları Hematoloji Onkoloji Eğitim ve Araștrrma Hastanesi Klinik Araştırmalar Etik Kurulu'ndan 2015-075 onayı alındi.

Yazarların Katkısı / Contribution of the Authors: ŞAHINÖZ A: Verilerin toplanması, analizi ve makalenin yazımı, BÜTÜN AYHAN A: Her aşamada çallşmaya ait tüm kontrollerin yapılması

Atı́ yazım șekli / How to cite: Sahinöz A, Bütün Ayhan A. Annelerin Bebeklik Döneminde Gelișime llișkin Bilgi ve Kaygı Düzeylerinin Değerlendirilmesi. Turkish $J$ Pediatr Dis 2020; 14: 249-57. 
Conclusion: According to the findings obtained from the study, it is necessary to plan studies to enhace mothers' knowledge level about child development prepare training programs and to disseminate these programs, and to increase the number of specialists who work with parents.

Key Words: Anxiety, Child development, Infancy, Mother's knowledge

\section{Giriș}

Bebeklik dönemi gelişim açısından kritik önem taşımaktadır. Bu kritik yıllarda ebeveynler özellikle de bebeğin bakım intiyaçlarını karşılayan anneler çocuğun ilk ve temel eğitimcisi rolündedir. Ayrıca anne bebek bağlanmasının da geliştiği bu dönemde, annelerin çocuklarının gelişimini desteklemek için onlara çeşitli uyaranlar sağlaması ve ilgi göstermesi gerekmektedir. Ebeveynlerin çocuklarına sağladıkları uyarandan zengin destekleyici bir ortam çocuğun gelişiminde oldukça büyük öneme sahiptir (1-3).

Annelerin bebeğin bakımı, özellikleri, davranışları ve hastalıkları ile ilgili bilgi eksikliği, bebeğin intiyaçlarını anlamada yetersizlik, yorgunluk, sosyal çevreden soyutlanma ve sosyal desteklerde yetersizlik annede stres ve kaygı yaratabilmekte, annelik rolüne uyumu zorlaştırmakta ve ebeveyn-bebek bağllı̆̆ını olumsuz etkileyebilmektedir (4). Bu nedenle annelere erken dönemde bebeklerin intiyaçları, gelişimleri ve bakımlarına ilişkin verilen eğitim, bebeklerin gelişim düzeylerinde olumlu değişiklikler yaratabilmektedir. Bu değişiklikler, çocuk okula başladıktan sonra yapılan müdahalelerden daha hızlı bir șekilde gerçekleșmekte ve daha fazla etki yaratmaktadır. Anne-babaların temel gelișimsel becerilerin kazanıldığı erken yıllarda, çocukla uygun iletișim kurabilme, doğru bakım ve uyaran verme ve çocuk eğitimi konularında aldıkları erken eğitim ve sağladıkları uyarandan zengin ortam çocuğun gelecek yașamında ortaya çıkabilecek gelişimsel problemleri önleyerek, topluma ekonomik ve sosyal olarak fayda sağlamaktadır (5).

Uyaran eksikliği, dünyada gelișmekte olan ülkelerde yașayan beș yaș altındaki 200 milyon çocuğun gelișimsel potansiyeline ulașamamasında ikinci ana neden olarak yer almaktadır $(6,7)$. Çocuk için erken uyarıcı çevrenin sağlanmamasının sadece gelișimsel durumdaki bir boșluğa yol açmayacağı, aynı zamanda duygusal yeteneklerdeki zayıflığa ve gelișimsel geriliğe de yol açacağı bilinmektedir (8). Uyaran eksikliği nedeniyle yaşanan gelişimsel sorunların en aza indirilmesi, uyaranların kalitesinin artırıması, ebeveyn-çocuk ilişsisinin güçlenmesi açısından ebeveynlerin çocuk gelișimine yönelik bilgi düzeyleri oldukça önemlidir. Ebeveynlik bilgisi kapsamında ise çocuk bakımı, çocuğun gelișimine destek olma gibi kavramlar yer alır ve ebeveynler çocukların yașamlarında önemli bir rol oynarlar $(9,10)$. Bunun yanı sıra ebeveynlerin çocukları ile ilgili kararlarını uzmanlar etkileyebilmektedir. Bunun sonucunda ebeveynler çocuklarının gelișimini nasıl destekleyeceklerini, hastalık anında ne yapacaklarını öğrenebilmekte ve bakımları ile ilgili doğru davranıșlarda bulunabilmektedirler. Ebeveynlerin bu durumlarla ilgili bilgi sahibi olması çocukların gelişimleri için hayati önem taşımaktadır (11-14).
Annelerin yeni rollerine uyum sağlamaya çalıștıkları çocuklarının yenidoğan ve 1-3 yaș döneminde, normal büyüme ve gelișme hakkında bilgi ve danıșmanlık almaya daha çok intiyaç duydukları ve bilgi almak için sağlık alanında uzman kişilere sık başvurduğu görülmektedir (15). Annelerin bu bilgiyi edinebileceği, problemlerini çözmelerine yardımcı olabilecek ve çocuklarının gelișimlerini destekleyici öneriler alabileceği uzmanların varlığı oldukça önemlidir. Yıldız' ın yaptığı bir çalışmanın sonuçlarına göre; kontrollü ve devamlı olarak danışmanlık hizmeti verilen primipar annelerin bebek bakımı ile ilgili bilgi düzeyinde önemli ölçüde artış, kaygı düzeylerinde azalma, annelik rolünden memnuniyette artıș sağlandığı görülmüștür (4).

Çocuk bakımı konusundaki bu bilgi eksikliği ve çevreden öğrenilen yanlıș uygulamaların, çoğu zaman çocuğun sağlı̆ı̆ı olumsuz etkileyerek büyüme ve gelişmede gecikmeye, çoğu önlenebilir hastalıkların sık görülmesine, morbidite ve hatta mortaliteye neden olabildiği bildirilmiştir. Genel gelişim basamakları hakkında bilgilendirilen annelerin çocuklarının yeteneklerini keşfetmesini sağlayacak bilişsel ve sosyal açıdan fırsat ortamları yaratma olasılığı artmaktadır (13,16-19). Huang ve ark.(9) 378 çocuk ve anneyi dâhil ettikleri çalsşmalarında annelerin çocuk gelişimi ile ilgili erken dönemdeki bilgi düzeyi ile anne-babalık davranışının kalitesi arasındaki ilișkiyi ölçmeyi amaçlamış; annelerin çocuk gelişimi konusundaki bilgi eksikliğinin annelik görevlerinin kalitesini, özellikle bebeğe bir şeyler öğretme becerisini olumsuz etkilediğini belirlemişlerdir.

Bu araştırmada 0-24 ay arasında bebeğe sahip olan annelerin bebeklik döneminde gelișime ilişkin bilgi ve kaygı düzeylerinin incelenmesi amaçlanmıştır.

\section{GEREÇ ve YÖNTEMLER}

Araștırma betimsel bir çalıșma olarak planlanmıştır. Araștırmanın örneklemini Ankara il merkezinde bulunan Kamu Hastaneler Kurumu'na bağlı çocuk hastanesinin sağlam çocuk polikliniklerine başvuran çalıșmaya katımaya gönüllü olan ve doğum haftası en az 37 hafta ve yașları 0-24 ay arasında olan bebeğe sahip 102 anne olușturmuștur.

\section{Veri Toplama Araçları}

$\mathrm{Bu}$ araştırmada veriler Aile Bilgi Formu, Annelerin Bebeklik ve Erken Çocukluk Dönemi Gelișimi ve Gelișimin Desteklenmesi Bilgisi Ölçeği/ The Caregiver Knowledge of Child Development Inventory (Gelişim Bilgisi Ölçeği) ve Durumluk-Sürekli Kaygı Ölçeği/ State Trait Anxiety Inventory (STAl)' nin Sürekli Kaygı Ölçeği (Kaygı Ölçeği) kullanılarak elde edilmiştir (20,23,24).

Aile bilgi formunda; bebeğin yaşı, cinsiyeti, kardeş sayısı, 
doğum sırası, doğum kilosu gibi bebeklere ilişkin bilgiler ile annelerin yaşı, öğrenim düzeyi, çocuk gelişimi ile ilgili bilgileri edindiği kaynaklar, çocuk gelişimci ile çocuğunun gelişimi ile ilgili görüşme yapma durumu ve ailenin gelir düzeyinin sorgulandığı yirmi beş soru yer almaktadır.

\section{Annelerin Bebeklik ve Erken Çocukluk Dönemi Gelişimi ve Gelişimin Desteklenmesi Bilgisi Ölçeği}

Annelerin Bebeklik ve Erken Çocukluk Dönemi Gelişimi ve Gelişimin Desteklenmesi Bilgisi Ölçeği; Ertem ve ark.(20) tarafından 2007 yllında geliştirilmiş ve geçerlik güvenirlik çalışması yapılmıştır. Ölçeğin iç tutarlı̆̆ı Cronbach alfa ile hesaplanmış ve toplam 20 maddeli ölçeğin iç tutarlıı̆ı $a=0.61$ bulunmuştur. Ölçek, 0-3 yaş arasında çocuğu olan annelerin bebeklik ve erken çocukluk dönemi gelişimi ve gelişimin desteklenmesi bilgisini ölçmek amacıyla geliştirilmiştir. Ölçeğin geliştirilmesi ile ilgili çalışma iki aşamada gerçekleştirilmiştir. Illk olarak, bakıcı bilgisini değerlendirmek için temel gelişimsel becerilerin ortaya çıkması ve desteklenmesine ilişkin yaşlar ile ilgili bir form geliştirimiştir. İkinci aşamada bu form Türkiye'de iki çalışmada bir alan araştırmasında kullanılmıştır. Ölçekteki soruların 10 tanesi gelişimsel beceriler, 10 tanesi de gelişimsel becerileri desteklemeye yönelik uyaranlar ile ilgilidir. Ölçekteki 20 sorudan yedisi bebeklerde zihinsel, sosyal duygusal gelişimi, altısı yürümeye yeni başlayan çocuklarda zihinsel, sosyal duygusal gelişimi, altısı motor becerileri ve biride ebeveynlerin ev kazalarına karşı güvenlik önlemleri ile ilgili bilgi düzeylerini sorgulamaktadır. Ölçekteki her bir maddenin hangi yaş aralığında yapılması gerektiği "Uluslararası Gelişimi İzleme ve Destekleme Rehberi (GiDR) referans alınarak ve uzmanların ortak görüşleri sonucunda belirlenmiştir $(21,22)$. Puanlamada, bakım verenin verdiği cevap doğru yaş aralı̆ıında ise iki puan, doğru yaş aralığından bir ay yukarıda ya da aşağı olursa bir puan, bunların dışında bir yaş aralığında ise sıfır puan almaktadır. Ölçekte ulaşılabilen en yüksek puan 40 puandır. Ölçekten alınan yüksek puan ile annelerin çocuk gelişimi ile ilgili bilgi düzeyinin yüksek olduğu, düşük puan ile de annelerin çocuk gelişimi ile ilgili bilgi düzeyinin düşük olduğu ön görülmektedir (20).

\section{Durumluk-Sürekli Kaygı Ölçeği (STAI)}

Durumluk- Sürekli Kaygı Ölçeği, Spielberger ve ark.(23) tarafindan 1970 yllında geliştirimiş, Öner ve Le Compte (24) tarafindan ise 1983 yllında Türk toplumuna uyarlaması yapılmıştır. Türkçe formun iç tutarlığı ve güvenirliği Kuder Richardson alfa güvenirliğinde Durumluk Anksiyete Ölçeği için 0.94 ile 0.96 arasında bulunmuştur. Durumluk ve sürekli kaygı düzeylerini 20' şer soru ile ayrı ayrı ölçen likert tipi bir ölçektir. Yüksek puanlar yüksek kaygı seviyelerini, düşük puanlar düşük kaygı seviyelerini gösterir. Ölçek, yirmişer maddelik Durumluk Kaygı ve Sürekli Kaygı Ölçekleri' nden oluşmaktadır. Durumluk Kaygı Ölçeği, bireyin belirli bir anda ve belirli koşullarda kendisini nasıl hissettiğini betimlemesini, "Sürekli Kaygı Ölçeği" ise bireyin genellikle kendisini nasıl hissettiğini betimlemesini gerektirir. Her iki ölçekte cevap seçenekleri dört tane olduğundan seçeneklerin ağırlık dereceleri birden dörde kadar değişmektedir. "Hiç" ile "Tamamılla" arasında değişen dört derecelik bir ölçektir. Her iki ölçekten elde edilen toplam puan değeri 20-80 arasında değişir. Yüksek puan yüksek kaygı seviyesini, düşük puan ise düşük kaygı seviyesini belirtir $(23,24)$.

\section{Veri Toplama Yöntemi}

Araştırmada kullanılan ölçme araçları için gerekli izinler alınmıştır. Araştırmanın yapılabilmesi için uygulamanın yapılacağı Eğitim ve Araştırma Hastanesi' nden gerekli izinler (2015-075) alınmıştır. Hastanenin Sağlam Çocuk Polikliniği' ne başvuran sağlıklı gelişim gösteren, herhangi bir engele sahip olmayan 0-2 yaş arasındaki bebeklerin annelerine çalsşma ile ilgili kısaca bilgi verilmiş ve görüşmenin yapılacağı uygun bir odaya yönlendirmiștir. Araştırmacılar tarafından annelere araştırma hakkında ayrıntıı bilgi verilmiş; katımaya gönüllü olan annelere sosyodemografik Özelliklerini belirlemek amacıyla "Aile Bilgi Formu", çocuk gelişimi hakkındaki bilgi düzeylerini belirlemek amacıyla "Annelerin Bebeklik ve Erken Çocukluk Dönemi Gelișimi ve Gelișimin Desteklenmesi Bilgisi Ölçeği", kaygı durumlarını belirlemek için ise "Durumluk ve Sürekli Kaygı Ölçeği" nin "Sürekli Kaygı Ölçeği" (SKÖ) karşlıklı görüşme yaparak uygulanmıştır.

\section{Verilerin Analizi}

Araştırmada elde edilen verilerin analizi için SPSS 17.0 bilgisayar programı kullanılmıştır. Araştırmada sosyodemografik verilerin değerlendirilmesinde sayı ve yüzdelik değerler kullanıımıştır. Araştırmada verilerin normallik dağılımları Shapiro Wilk Testi ile hesaplanmıştır ve verilerin normal dağılım gösterdiği belirlenmiștir. Annelerin Gelișim Bilgisi Ölçeği' nden aldıkları puanların ortalaması ile Kaygı Ölçeği' nden aldıkları puan arasındaki ilişki ise Pearson Korelasyon Katsayısı kullanılarak yorumlanmıştır. İstatistiksel anlamlıık sınıı olarak $p<0,05$ kabul edilmiştir.

Sosyodemografik değişkenlerin Gelişim Bilgisi Ölçeği ve Kaygı Ölçeği ile karşılaştııımasında parametrik testlerden Tek yönlü varyans analizi (ANOVA) ve t-testi kullanılmış; varyans analizi sonucunda farkllığın hangi grup/ gruplardan kaynaklandığının karşılaştırılmasında da Tukey çoklu karşılaştırma testi kullanıımıştır. Annelerin çocuk gelişimi bilgi ölçeğinden aldıkları puanların ortalaması ile kaygı ölçeğinden aldıkları puan arasındaki ilişki ise Pearson Korelasyon Katsayısı kullanılarak yorumlanmıştır.

\section{BULGULAR}

Araştırmada yer alan annelere ve bebeklerine ait sosyodemografik veriler Tablo l' de yer almaktadır. Araştırmaya katılan annelerin, \% 41.2' sinin 26-32 yaș aralığında olduğu, \% 39.2' sinin ortaokul mezunu olduğu, \%70.6'sının çekirdek aile olarak yaşadığı belirlenmiştir. Annelerin bebeklerinin \%52'si kız, \%49'u ise erkektir. Bebeklerin \% 55.9'i 0-12 ay arasındadır. 
Tablo I. Annelerin ve Bebeklerin Sosyodemografik Özellikleri.

\begin{tabular}{|c|c|c|}
\hline Yaş & $\mathbf{n}$ & $\%$ \\
\hline 18-25 yaş & 35 & 34.3 \\
\hline 26-32 yaș & 42 & 41.2 \\
\hline 33-40 yaș & 25 & 24.5 \\
\hline \multicolumn{3}{|l|}{ Öğrenim düzeyi } \\
\hline İlkokul mezunu & 20 & 19.6 \\
\hline Ortaokul mezunu & 40 & 39.2 \\
\hline Lise mezunu & 22 & 21.6 \\
\hline Lisans/lisansüstü mezunu & 20 & 19.6 \\
\hline \multicolumn{3}{|l|}{ Çalışma durumu } \\
\hline Çalıșıyor & 13 & 12.7 \\
\hline Çalışmıyor & 89 & 87.3 \\
\hline \multicolumn{3}{|l|}{ Aile tipi } \\
\hline Çekirdek aile & 72 & 70.6 \\
\hline Geniş aile & 30 & 29.4 \\
\hline \multicolumn{3}{|l|}{ Gelir düzeyi } \\
\hline 1000 TL altı & 15 & 14.7 \\
\hline 1001-2000 TL arası & 44 & 43.1 \\
\hline 2001-3000 TL arası & 17 & 16.7 \\
\hline 3001-4000 TL arası & 14 & 13.7 \\
\hline 4001 TL ve üzeri & 12 & 11.8 \\
\hline \multicolumn{3}{|c|}{ Bebeklerin Sosyodemografik Özellikleri } \\
\hline Yaş & $\mathbf{n}$ & $\%$ \\
\hline $0-6$ ayllk & 26 & 25.5 \\
\hline 7-12 aylik & 31 & 30.4 \\
\hline 13-18 aylik & 26 & 25.5 \\
\hline 19-24 aylik & 19 & 18.6 \\
\hline \multicolumn{3}{|l|}{ Cinsiyet } \\
\hline $\mathrm{K} I \mathrm{z}$ & 53 & 52 \\
\hline Erkek & 49 & 48 \\
\hline \multicolumn{3}{|l|}{ Doğum Sırası } \\
\hline İlk çocuk & 47 & 46.1 \\
\hline Son çocuk & 55 & 53.9 \\
\hline \multicolumn{3}{|l|}{ Kardeş sayısı } \\
\hline Tek çocuk & 46 & 45.1 \\
\hline İki kardeş & 33 & 32.4 \\
\hline Üç kardeş ve üzeri & 23 & 22.5 \\
\hline \multicolumn{3}{|l|}{ Bebeğin doğum kilosu } \\
\hline $2501-3000 \mathrm{gr}$ & 27 & 26.5 \\
\hline $3001-3500 \mathrm{gr}$ & 53 & 52 \\
\hline 3501 gr ve üzeri & 22 & 21.6 \\
\hline
\end{tabular}


Tablo II. Annelerin Bebeklik ve Erken Çocukluk Dönemi Gelişimi ve Gelişimin Desteklenmesi Bilgisi Ölçeği' ne Ait Sorulara Verilen Yanıtlar.

\begin{tabular}{|c|c|c|}
\hline \multirow{2}{*}{$\begin{array}{l}\text { Annelerin Bebeklik ve Erken Çocukluk Dönemi Gelişimi ve Gelişimin Desteklenmesi Bilgisi } \\
\text { Ölçeği' ne Ait Örnek Sorular }\end{array}$} & \multicolumn{2}{|c|}{ Yanlış cevap ( 0 puan) } \\
\hline & $\mathbf{n}$ & $\%$ \\
\hline Çocuklar ne zaman görmeye başlarlar? & 31 & 30.4 \\
\hline Çocuklar ne zaman tek tek anlamlı sözcükler söylemeye başlarlar? & 44 & 43,1 \\
\hline Çocuklar ne zaman yürümeye başlarlar? & 10 & 9.8 \\
\hline Çocuklarla konuşmaya en erken ne zaman başlanır? & 27 & 26.5 \\
\hline Çocuklara çizip boyamaları için kalem, kâğıt vermeye en erken ne zaman başlanır? & 21 & 20.6 \\
\hline Çocukların sırtlarını destekleyip oturtmaya en erken ne zaman başlanır? & 68 & 66.7 \\
\hline Çocuklarla kitap bakmaya en erken ne zaman başlanır? & 85 & 83.3 \\
\hline
\end{tabular}

Anne bilgi formunda yer alan çocuk gelişimine ilişkin sorulara verilen cevaplara göre annelerin çoğunluğunun (\%62.7) çocuk gelişimi ile ilgili yazılı materyal okuduğu belirlenmiştir. Annelerin çoğunluğu (\% 63.7) bebeklerinin gelişimleri ile ilgili yeterli bilgiye sahip olmadıklarını ifade etmiştir. Bebeklerinin gelişimleri ile ilgili yeterli bilgi sahibi olduğunu düşünen annelerden yalnızca \%24.3'ü bu bilgiyi bir uzmandan edindiklerini belirtmiştir. Annelerin büyük çoğunluğu (\%90.2) çocuk gelişimci ile görüşmediğini belirtirken; çocuk gelişimci ile görüşen annelerin \% 80'i bu danışmanlık hizmetinin gelişim ile ilgili bilgi düzeyini artırdığını dile getirmiştir. Annelerin yalnızca \% 12.7'si çocukları ile ilgili merak ettikleri şeyleri hekim ya da sağlık çalışanına danıştı̆̆ını ifade etmiştir.

Gelişim Bilgisi Ölçeği' nde yer alan gelişimin dönüm noktaları ile ilgili bazı sorulara ilişkin tanımlayıcı istatistikler Tablo II' te görülmektedir. Soru 2'de "Çocuklar ne zaman görmeye başlarlar?" sorusuna annelerin \% 30.4'ü, "Çocuklar ne zaman tek tek anlamlı sözcükler söylemeye başlarlar?" sorusuna ise \% 43.1'i yanlış cevap vermiştir. Çocukların motor gelişimleri ile ilgili "Çocuklar ne zaman yürümeye başlarlar?" sorusuna ise annelerin büyük çoğunluğunun (\%83.3) doğru cevap verdiği, "Çocukların sırtlarını destekleyip oturtmaya en erken ne zaman bașlanır?" sorusuna ise doğru cevap veren annelerin oranının oldukça düşük (\%11.8) olduğu dikkat çekmiştir. Annelerin çocuklarına uyaran verme durumlarını sorgulayan "Çocuklarla konuşmaya en erken ne zaman başlanır?" sorusuna annelerin \% 70.6'sı doğru cevap vermiştir. Yine uyaranlar ile ilgili bir başka soru olan "Çocuklara çizip boyamaları için kalem, kâğıt vermeye en erken ne zaman bașlanır?" sorusuna annelerin \% 20.6'sının; "Çocuklarla kitap bakmaya en erken ne zaman başlanır?" sorusuna ise \% 83.3'ünün yanllş cevap verdiği görülmüştür.

Çallşmaya dâhil edilen annelerin sosyodemografik değişkenler açısından Gelişim Bilgisi ve Kaygı Ölçeği' nden aldıkları puanların ortalaması Tablo III' te verilmiştir. Annelerin yaşları, öğrenim düzeyi, gelir düzeyi ve sahip oldukları çocuk sayısı Gelişim Bilgisi Ölçeği puan ortalamalarında anlamlı bir farkllık yaratmamıştır. Kaygı Ölçeği puan ortalamaları incelendiğinde, annelerin yaşı ve sahip oldukları çocuk sayısı kaygı düzeylerinde anlamlı bir farklılık yaratmazken öğrenim düzeyi ve gelir düzeyi kaygı düzeylerinde istatistiksel olarak anlamlı bir farkllık yaratmıştır $(p<0,01)$. Gruplar arasındaki farklıı̆ın kaynağını bulmak için yapılan Tukey çoklu karşlaştırma testi sonucunda, ortaokul mezunu olan anneler ile lisans/ lisansüstü mezunu olan annelerin Kaygı Ölçeği'nden aldıkları puan ortalamaları arasında anlamlı bir fark olduğu belirlenmiştir $(p=0.009)$. Lisans/ lisansüstü mezunu annelerin Kaygı Ölçeği puan ortalamaları diğer öğrenim düzeyine sahip annelerin puan ortalamalarından daha düşüktür (F3-98= 4.483; $\mathrm{p}<0.01)$. Geliri 1001-2000 TL arasında olan annelerin yüksek

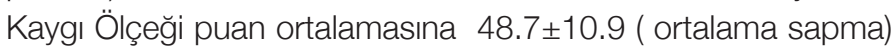
sahip olduğu tespit edilmiştir. Ailelerin gelir düzeyi ile kaygı puan ortalamaları arasında fark istatistiksel olarak anlamlıdır $(p<0.05)$. Geliri 1001-2000 TL arasında olan annelerin kaygı düzeyi, diğer gelir düzeyine sahip olanlardan daha yüksektir (F4-97= 4.305; $p<0.05)$. En yüksek kaygı düzeyine, geliri 1001-2000 TL arasında olan annelerin sahip olduğu belirlenmiştir.

Annelerin çocuk gelişimi ile ilgili yazılı materyal okuma durumuna ve çocuk gelişimci ile görüşme durumuna göre Gelişim Bilgisi Ölçeği ve Kaygı Ölçeği puan ortalamalarına ait verilere Tablo IV' te yer verilmiştir. Annelerin çocuk gelişimi ile ilgili herhangi bir yazılı materyal okumaları bebeklik döneminde gelişime ilişkin bilgi ölçeği puan ortalamalarında anlamlı bir farkllık yaratmıştır $(p<0.05)$. Buna göre çocuk gelişimi ile ilgili herhangi bir yazilı materyal okuyan annelerin Gelişim Bilgisi Ölçeği puanları $23.7 \pm 4.7$ okumayanların puanları $21.4 \pm 3.8$ göre daha yüksektir. Annelerin çocuk gelişimi ile ilgili yazılı materyal okuma durumuna göre Kaygı Ölçeği puan ortalamaları incelendiğinde çocuk gelişimi ile ilgili herhangi bir yazılı materyal okumalarının kaygı düzeylerinde anlamlı bir farkllık yarattığı belirlenmişsir. Çocuk 
Tablo III. Annelerin Sosyodemografik Özelliklerine Göre Annelerin Bebeklik ve Erken Çocukluk Dönemi Gelişimi ve Gelişimin Desteklenmesi Bilgisi Ölçeği ve Sürekli Kaygı Ölçeği Puan Ortalamalarına Ilişkin Dağıımlar.

\begin{tabular}{|c|c|c|c|c|c|c|}
\hline \multicolumn{4}{|c|}{$\begin{array}{l}\text { Annelerin Bebeklik ve Erken Çocukluk Dönemi Gelişimi ve Gelişimin } \\
\text { Desteklenmesi Bilgisi Ölçeği (en küçük-en büyük puan) }\end{array}$} & \multicolumn{3}{|c|}{$\begin{array}{l}\text { Sürekli Kaygı Ölçeği } \\
\text { (en küçük-en büyük puan) }\end{array}$} \\
\hline Gruplar & ortalama & SS & p & ortalama & SS & p \\
\hline \multicolumn{7}{|l|}{ Yaş } \\
\hline $18-25$ yaş & 22.5 & 4.1 & \multirow{3}{*}{0.809} & 48.2 & 10.2 & \multirow{3}{*}{0.11} \\
\hline 26-32 yaş & 23.0 & 5.3 & & 42.8 & 11.7 & \\
\hline 33-40 yaş & 23.2 & 3.9 & & 45.8 & 11.4 & \\
\hline \multicolumn{7}{|l|}{ Öğrenim düzeyi } \\
\hline İlkokul mezunu & 22.8 & 3.8 & \multirow{4}{*}{0.062} & 48 & 13.8 & \multirow{4}{*}{$0.005^{\star}$} \\
\hline Ortaokul mezunu & 22.3 & 4.9 & & 48.8 & 9.2 & \\
\hline Lise mezunu & 21.8 & 3.7 & & 42.4 & 9.6 & \\
\hline Lisans/lisanüstü mezunu & 25.3 & 4.7 & & 39.2 & 11.3 & \\
\hline \multicolumn{7}{|l|}{ Gelir düzeyi } \\
\hline 1000 TL altı & 22.9 & 5.3 & \multirow{5}{*}{0.448} & 48.2 & 8.4 & \multirow{5}{*}{$0.003^{*}$} \\
\hline 1001- $2000 \mathrm{TL}$ & 22.3 & 4.4 & & 48.7 & 10.9 & \\
\hline 2001-3000 TL & 23.1 & 4.3 & & 40.2 & 9.6 & \\
\hline $3001-4000 \mathrm{TL}$ & 22.4 & 3.2 & & 37.5 & 9.8 & \\
\hline 4001 TL ve üzeri & 25.2 & 5.8 & & 45.9 & 13.3 & \\
\hline \multicolumn{7}{|l|}{ Çocuk sayısı } \\
\hline Tek çocuk & 23.2 & 4.8 & \multirow{3}{*}{0.327} & 45.2 & 10.9 & \multirow{3}{*}{0.991} \\
\hline İki çocuk & 21.9 & 4.6 & & 45.6 & 10.5 & \\
\hline Üç çocuk ve daha fazla çocuk & 23.7 & 3.9 & & 45.3 & 13.4 & \\
\hline
\end{tabular}

${ }^{*} p<0.05$, SS: Standart sapma

gelişimi ile ilgili yazılı materyal okuyan annelerin Kaygı Ölçeği puanları 42.3 \pm 10.3 , okumayan annelerin puanlarına $50.5 \pm 10.9$ göre daha düşüktür. Çocuk gelişimi ile ilgili yazilı materyal okumayan annelerin, okuyan annelere göre daha kayglı olduğu bulunmuştur. Annelerin çocuk gelişimci ile görüşme durumları Gelişim Bilgisi Ölçeği puan ortalamalarında istatistiksel olarak anlamlı farklık yaratmıştır. Buna göre çocuk gelişimci ile

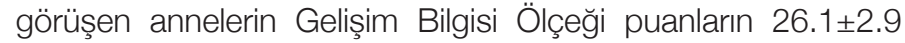
görüşmeyenlerin puanlarına göre $22.5 \pm 4.5$ daha yüksektir. Çocuk gelişimci ile görüşen ve görüşmeyen annelerin Kaygı Ölçeği puan ortalamaları arasında fark bulunamamıştır ( $p>0.05$ ).

Annelerin çocuk gelişimine yönelik bilgi ölçeğinden aldıkları puan ortalamaları ile kaygı ölçeğinden aldıkları puan ortalamaları arasındaki ilişkinin incelenmesi için yapılan Pearson Korelasyon Katsayı sonuçlarında bu iki ölçek arasında negatif yönlü bir ilişki bulunmuștur $(r=-0.200 ; p<0.05)$. Annelerin bilgi düzeyleri arttıkça kaygı düzeylerinin azaldığı belirlenmiştir.

\section{TARTIŞMA}

Annelerin bebeklik dönemine ilişkin gelişim ile ilgili bilgi sahibi olmaları onların bebekleri ile iletişimini güçlendirecek, uygun uyaranlar vermelerine olanak sağlayacaktır. Bu düşünceden yola çıkarak ülkemizde daha önce anne sütü ile beslenme, emzirme teknikleri ve faydaları, ek besinler ile ilgili ebeveyn bilgisini değerlendiren birçok çalışma yapılmışıı (17,25-27). Fakat annelerin bebeklerinin gelişimleri ile ilgili bilgi düzeylerini sorgulayan çalışmalar yurtdışında sayıca fazla iken ülkemizde bununla ilgili sınırlı sayıda çalışma vardır (20).

Çalışma bulgularından yaşa göre annelerin Gelişim Bilgisi Ölçeği puan ortalamaları incelendiğinde, 33-40 yaş annelerin ölçekten aldıkları puan ortalamasının diğer yaş gruplarına göre daha yüksek olduğu görülse de annelerin yaşlarının puan ortalamalarında istatistiksel olarak anlamlı bir farklllik yaratmadığı belirlenmiştir. Ayrıca annelerin öğrenim düzeyi, gelir düzeyi ve sahip oldukları çocuk sayısı da Gelişim Bilgisi Ölçeği puanlarında anlamlı bir farkllık yaratmamıştır. Bu bulgunun annelerin yaşının ilerlemesine paralel olarak bebeklerinin de gelişimsel olarak ilerlemesinden dolayı yeni bilgilere intiyaç duymasından kaynaklanabileceği düşünülmektedir.

Araştırmada annelerin kaygı düzeyleri annelerin yaşına göre farkllık göstermezken, öğrenim durumunun kaygı düzeylerinde anlamlı bir farkllık yarattığı belirlenmiştir. Annelerin öğrenim durumu arttıkça kaygı düzeylerinin azaldığı belirlenmiştir. Lisans/ 
Tablo IV. Annelerin Çocuk Gelişimi Ile Ilgili Yazilı Materyal Okuma ve Çocuk Gelişimci Ille Görüşme Yapma Durumlarına Göre Annelerin Bebeklik ve Erken Çocukluk Dönemi Gelişimi ve Gelişimin Desteklenmesi Bilgisi Ölçeği/ Sürekli Kaygı Ölçeği Puan Ortalamalarına liş̧kin Dağllımlar

Annelerin Bebeklik ve Erken Çocukluk Dönemi Gelişimi ve Gelişimin Desteklenmesi Bilgisi Ölçeği

\section{Gruplar}

n 64 38

10

92 ortalama

4.7

Yeterli bilgisi olan

Yeterli bilgisi olmayan

\section{Çocuk gelişimci ile görüşme yapma durumu}

Yeterli bilgisi olan

Yeterli bilgisi olmayan

\section{Sürekli Kaygı Ölçeği}

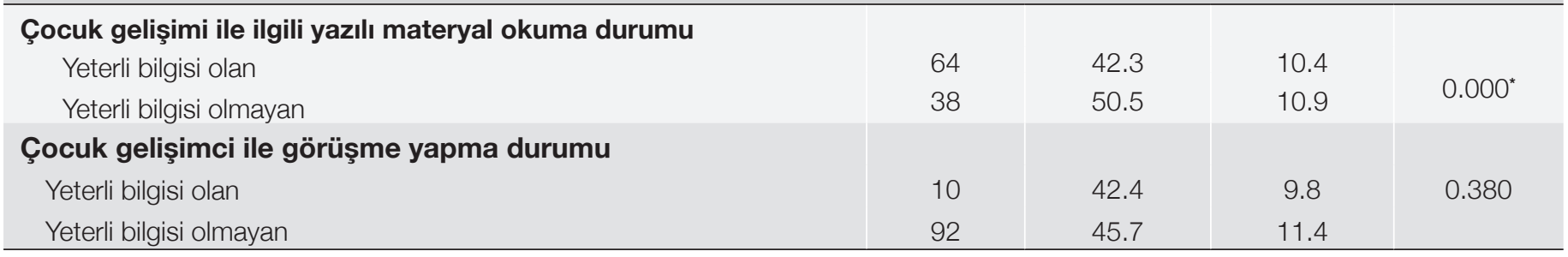

${ }^{*} p<0.05$, SS: Standart sapma, SD: Serbestlik değeri

lisansüstü mezunu annelerin kaygı düzeylerinin ilkokul, ortaokul ve lise mezunu annelerin kaygı düzeylerinden daha düşük olduğu belirlenmiștir. Toros ve ark. (28) yaptığı bir çalıșmada, eğitim düzeyindeki düşüklüğün, çocuk bakımı ile ilgili bilgi eksikliğinin ve sorun çözmede yetersizliğin, annelerin kaygı düzeyini artırdığını ifade etmiştir. Bir bașka çalışmanın sonucuna göre ise ilköğretim düzeyindeki annelerin, orta ve yükseköğrenim grubunda olan annelerden; orta öğrenim grubundaki annelerin de yükseköğrenim grubunda olan annelerden daha çok kaygılı oldukları belirlenmiștir (29). Bu bulgular araştırma sonuçları ile paralellik göstermektedir.

Annelerin sahip olduğu çocuk sayısına göre Gelişim Bilgisi Ölçeği ve Kaygı Ölçeği puan ortalamaları incelendiğinde grupların her iki ölçekteki puan ortalamalarının birbirine yakın olduğu ve bu gruplar arasında istatistiksel olarak anlamlı bir fark olmadığı saptanmıștır. Bu durumun annelerin her bebek sahibi olduklarında doğum sonrası dönemde kaygı yaşayabilmesinden kaynaklı olabileceği düşünülmektedir. Dik ve ark.' nın (30) yaptığı çalışmada doğum yapan annelerin bebek bakımı, beslenmesi ve hijyen konusunda bilgileri araștırımış, annenin yașı, çocuk sayısı ve çalışma durumunun bilgi düzeylerini etkilemediği fakat annenin öğrenim düzeyi arttıkça aldıkları puanların da arttığı belirlenmiștir.

Araştırmaya dâhil olan annelerin gelir düzeyinin, çocuk gelişimi ile ilgili bilgi düzeylerinde farklllık göstermediği ancak kaygı düzeylerinde anlamlı bir farkllık yarattı̆̆ı tespit edilmiștir. Annelerin gelir düzeyi arttıkça kaygılarının azaldığı görülmektedir Araştırma sonuçlarına göre en çok kaygılı grup gelir düzeyi

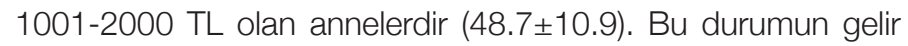

düzeyi düșük olduğunda geçinmenin ve çocukların intiyaçlarını karșılamanın zorlașmasından, annelerin bu durumu fazlasıyla düşünmelerinden kaynaklandığı düşünülmektedir. Coșkun ve Akkaş yaptığı çalışma sonucunda gelir düzeyinin azalmasının kaygı düzeyinde artışa neden olduğunu bulmuştur. Engelli çocuğu olan annelerle çalışan Erhan ve ark. (31) ile Görgü ve ark. (32) annelerin eğitim düzeyi ve gelir düzeyinin azalmasının kaygı düzeylerinin artmasına ve sosyal destek algılama düzeylerinde azalmaya neden olduğunu belirlemiştir (29).

Annelerin çocuk gelişimine yönelik yazılı materyal okumalarının annelerin çocuk gelişimi ile ilgili bilgi düzeyini artırdığı bulunmuştur. Buna göre herhangi bir kaynak okuyan annelerin bilgi düzeyi okumayanlara oranla yüksektir. Bornstein ve ark.'da (33) yaptığı çalışma ile annelerin çocuk gelişimine ilişkin yazlı materyal veya kitap okumalarının bilgi düzeyine doğrudan etki ettiğini ortaya koymuştur. Annelerin çocuk gelişimci ile görüşme yapma durumları da çocuk gelişimi ile ilgili bilgi düzeylerinde istatistiksel olarak anlamlı bir farklılık yaratmıştır. Çalışma bulguları annelerin çocuk gelişimci ile görüşsme yapmalarının çocuk gelişimi ile ilgili bilgi düzeyini artırdığı yönündedir. Çocuk Gelişimci ile görüşen annelerin Gelişim Bilgisi Ölçeği puan ortalamaları, görüşmeyen annelerin puan ortalamalarına göre anlamlı düzeyde yüksektir. Annelerin bebek bakımı ve ebeveynlik hakkında kendilerini yeterli hissetmesini sağlayan faktörlerden biri bebek bakımı ve gelişimi ile ilgili endişe ve sıkıntılarını gidermeye yardımcı olan danışmanlık hizmetidir. Sürekli değişimin yaşandığı bu dönemde bilgi verme, danışmanlık yapma ve ebeveynlerin endișelerini giderme gibi yaklaşımların, özellikle doğumdan sonraki ilk üç ayda anneliğe uyum ile annenin kaygılarını giderme ve bebek 
bakımı konusunda annenin öz güven geliştirmesinde önemli olduğu belirtilmiş, annelik rolüne uyumda öz güven ve prenatal dönemde başlayan sosyal destek arasında pozitif bir ilişki olduğu ifade edilmiştir (34-36). Annelerin çocuk gelişimci ile görüşme yapma durumlarına göre Kaygı Ölçeği puan ortalamaları incelendiğinde, çocuk gelişimci ile görüşen annelerin kaygı düzeylerinin daha düşük olduğu görülse de istatistiksel olarak anlamlı fark bulunamamıştır. Bunun yanı sıra annelerin çocuk gelişimi ile ilgili yazilı materyal okuma durumlarının kaygı düzeylerinin azalması yönünde anlamlı bir fark yarattığı belirlenmiştir. Çocuk gelişimi ile ilgili herhangi bir yazıı materyal okuyan annelerin okumayanlara oranla daha az kayglı olduğu bulunmuştur. Tribotti ve ark.(7) ile Snelson ve ark.(37) yaptıkları çalışmalar sonucunda bilginin stresi azalttığı, bunun da başarıı bir gebelik ve ebeveynliğe uyum süreci sağladığını belirtmişlerdir. Bu bulgular çalışmamızın sonuçlarını desteklemektedir.

Annelerin Gelişim Bilgisi Ölçeği'nde yer alan bazı sorulara verdikleri cevaplar incelendiğinde, özellikle motor gelişim ile ilgili sorulara doğru cevap verenlerin; dil gelişimi ile ilgili sorulara ise yanlış cevap verenlerin oranının ise yüksek olduğu görülmektedir. Bu durum annelerin bebeklerinin motor gelişim ile ilgili kilometre taşlarını özellikle takip edip uzun süre akıllarında tuttuklarına, "babıldama" döneminde bebeklerinin çıkardıkları ses tekrarlarını anlamlı kelime olarak değerlendirdiklerine ve uyaranlarla ilgili bilgi düzeyinin giderek artmasına bağı olabileceği düşünülmektedir. Ertem ve ark.' nın (20) gelişmekte olan ülkelerde annelerin çocuk gelişimine ilişkin bilgi düzeyini inceledikleri çalışmada, annelerin büyük çoğunluğunun motor gelişim ile ilgili sorulara doğru cevap verdikleri, dil gelişimi ve uyaranlarla ilgili sorulara ise yanlış cevap verdikleri ortaya konmuştur.

Araştırma sonucuna göre annelerin bilgi düzeyleri arttıkça kaygı düzeylerinde azalma olduğu tespit edilmiştir Little ve Lewis (38) yaptıkları çalışmada, annelerin bebeklerine yenidoğan döneminde yapılan topuk kanı alma gibi işlemlerin niçin yapıldığını bilmesi, annenin kaygılarını azaltmak ve kendini daha yeterli hissetmesini sağlamak için önemli olduğunu vurgulamıştır. Gürel ve ark. (39) çalışmalarında herhangi bir konu ile ilgili bilgi sahibi olmanın, bilgisizliğin yarattığı korku ve kaygıyı azaltıcı bir etken olduğunu, bilgi sahibi olmanın aynı zamanda durum üzerinde kontrol sağladığını, probleme odakı baş etme stratejilerinin uygulanmasını sağladığını belirtmişlerdir.

\section{SONUÇ ve ÖNERILER}

Araştırma sonucunda elde edilen bulgulara göre; annelerin çocuk gelişimi ile ilgili herhangi bir kaynaktan bilgi edinmeleri hem bilgi düzeyini artırmakta hem de kaygı düzeylerinde azalma sağlamaktadır. Bu nedenle ebeveynlerin okuyabileceği bu tür kaynakların yaygınlaştırıması ve ulaşılabilir olması, ebeveynler için hazırlanan eğitim programlarına ebeveynlerin katıım sayısını artırma politikalarının geliştirimesi önerilmektedir. Çocuk gelişimci ile görüşen annelerin gelişim ile ilgili bilgi düzeyleri artıı̆ı gibi kaygıları da azalmaktadır. Özellikle Sağlık Bakanlı̆̆ı tarafindan yürütülen "Gebe İzlem Protokolü" ve "Bebek İzlem Protokolü" kapsamında bebeklerin doğumlarından çok kısa bir süre sonra birinci basamak sağlık hizmeti veren kuruluşlarda takip edildiği bilindiğinden çocuk gelişimcilerin bu kuruluşlarda istihdamının sağlanması önerilmektedir.

\section{KAYNAKLAR}

1. Bertan M, Haznedaroğlu D, Koln P,Yurdakök K, Doğan BG. Ülkemizde erken çocukluk gelişimine ilişkin yapılan çalışmaların derlenmesi 2000-2007. Çocuk Sağlığı ve Hastalıkları Dergisi 2009; 52:1-8.

2. Kılınç EF. Anne eğitim programı ile anne çocuk etkileşim programının 24-36 aylık çocukların bilişsel becerilerine ve annelerin çocuk yetiştirme davranıșlarına etkisinin incelenmesi. Doktora Tezi. Konya: Selçuk Üniversitesi, 2011.

3. Shonkoff JP, Meisels SJ. Handbook of early childhood intervention. 2nd ed. New York: Cambridge University Pres, 2000.

4. Yıldız D. Çocuk sağlığı ve hastalıkları polikliniği sağlam bebek ünitesinde hemşirenin planlı hemşirelik eğitimi ve danışmanlık hizmetlerinin değerlendirilmesi. Doktora Tezi. Ankara: 2003.

5. Ceber $\mathrm{H}$. Normal ve Zihinsel engelli bebeklerde anne-bebek etkileşiminin karşılaştırmalı olarak incelenmesi. Yüksek Lisans Tezi. Ankara: Ankara Üniversitesi, 1998.

6. Grantham-Mcgregor S, Cheung YB, Cueto S, Glewwe P, Richter L, Strupp B, et al. Developmental potential in the first 5 years for children in developing countries. Lancet 2007;369: 60-70.

7. Tribotti S, Lyons N, Blackburn S, Stein M, Withers J. Nursing diagnoses for the postpartum women. JOGNN 1988;17: 410-5.

8. Stewart JC. Counseling parents of exceptional children. London: Charles E. Merrill Publishing Company, 1986.

9. Keng-Yen Huang, Margaret O'Brien Caughyb, Janice L Genevroc, Therese $L$ Miller. Maternal knowledge of child development and quality of parenting among white, african-american and hispanic mothers. Applied Developmental Psychology 2005;26:149-70.

10. Reich S. What do mothers know? Maternal knowledge of child development. Infant Ment Health J 2005;26:143-56.

11. Benasich AA, Brooks-Gunn J. Maternal attitudes and knowledge of child- rearing: associations with family and chills outcomes. Child Development 1996;67:1186-205.

12. Bornstein MH, Cote LR. Who is Sitting Across From Me? Immigrant mothers' knowledge of parenting and children's development. Pediatrics 2004; 114: 557-64.

13. Miller SA. Parents beliefs about their children's cognitive development. Child Development 1988;59: 259-85.

14. Murphy DA. Constructing the child: Relations between parents' beliefs and child outcomes. Dev Rev 1992;12:199-232.

15. Marks MG. The normal newborn. Broadribb's Introductory Pediatric Nursing. 5. Ed. Philadelphia: Lippincott Company, 1998.

16. Hunt McV J, Paraskevopoulos J. Children's psychological development as a function of the inaccuracy of their mother's knowledge of their abilities. Journal of Genetic Psychology 1980; 136: 285-98.

17. Özer A, Taş F, Ekerbiçer HÇ. Knowledge and behaviour of the mothers having 0-6 month old babies about the breast milk and breast feeding. TAF Prev Med Bull 2010; 9: 310-20. 
18. Raymond CT. Identifying patterns of developmental delays can help diagnose neurodevelopmental disorders. Clin Pediatr (Phila) 2006;45: 509-17.

19. Roopnarine JL, Logie C, Davidson KL, KrishnakumarA, Narine L. Caregivers' knowledge about children's development in three ethnic groups in trinidad and tobago. Parenting: Science and Practice 2015; 15: 229-46.

20. Ertem IÖ, Atay G, Doğan DG, Bayhan A, Bingöler BE, Gök CG, et al. Mother's knowledge of young child development in a developing country. Child: Care, Health and Development 2007;33:728-37.

21. Ertem Öztürk I, Krishnamurthy V, Mphelekedzeni CM, Sguassero $\mathrm{Y}$, Balta $\mathrm{H}$, et. al. Similarities and differences in child development from birth to age 3 years by sex and across four countries: A crosssectional, observational study. Lancet Glob Health 2018;6:279-91.

22. Ertem IÖ, Doğan DG, Gök CG, Kızılateş SU, Çalışkan A, Atay G, et al. A guide for monitoring child development in low- and middleincome countries. Pediatrics 2008;121:e581-9.

23. Spielberger CD, Gorsuch R, Lushene RE. Manual forth estate-trait anxiety inventory. Palo Alto, NY: Consulting Psychologists Press, 1970.

24. Öner N, Le Compte A. Süreksiz Durumluk/sürekli kaygı envanteri el kitabı, 1. Baskı. İstanbul: Boğaziçi Üniversitesi Yayınları, 1983; 1-26.

25. Uslu S, Can E, Özdemir $H$, Bülbül A. Bir yenidoğan ünitesinde annelerin anne sütü ile beslenme bilgi düzeyleri. Çocuk Dergisi 2010; 9: 82-5.

26. Samlı G, Kara B, Cöbek ÜP, Samlı B, Sarper N, Gökalp AS. Annelerin emzirme ve süt çocuğu beslenmesi konusundaki bilgi, inanış ve uygulamaları: Niteliksel bir araştırma. Marmara Medical Journal 2006;19:13-20.

27. Eker A, Yurdakul M. Annelerin bebek beslenmesi ve emzirmeye ilişkin bilgi ve uygulamaları. Sted 2006;15:158-63.

28. Toros F, Tot Ş, Düzovalı Ö. Kronik hastalığı olan çocuklar, anne ve babalarındaki depresyon ve anksiyete düzeyleri. Klinik Psikiyatri 2002;5:240-7.
29. Coşkun Y, Akkaş G. Engelli çocuğu olan annelerin sürekli kaygı düzeyleri ile sosyal destek algıları arasındaki ilișki. Ahi Evran Üniversitesi Kırşehir Eğitim Fakültesi Dergisi (KAFAD) 2009;10:21327.

30. Dik K, Koyuncuoğlu E, Çelik T, Korkmaz A. Annelerin bebek bakımı ve beslenmesi ile ilgili bilgi düzeyleri. Çocuk Sağlığı ve Hastalıkları Dergisi 2012;55:77-81.

31. Erhan GG. Zihinsel engelli çocuğu olan annelerin umutsuzluk, karamsarlık, sosyal destek algılarının ve gelecek planlarının incelenmesi. Yayınlanmamış Yüksek Lisans Tezi. Ankara: Ankara Üniversitesi, 2005.

32. Görgü E. 3-7 Yaș arası otistik çocuğa sahip olan annelerin algıladıkları sosyal destek düzeyleri ile depresyon düzeyleri arasındaki ilişki. Yayınlanmamış Yüksek Lisans Tezi. İstanbul: Marmara Üniversitesi, 2005.

33. Bornstein MH, Cote LR, Haynes OM, Hahn CS, Park Y. Parenting knowledge: Experiential and sociodemographic factors in Europe an American mothers of young children. Dev Psychol 2010; 46:1677-93.

34. Clemons RM. Issues in newborn care. J Primary Care 2000; 27 : 251-67.

35. Gill K. Nursingcare of Mothers. InDwelling E, Nicholas FH (eds). Maternal-newborn nursing: Theory and practice. 1st ed. Philadelphia: WB Saunders Co 1997: 992-1020.

36. Moran CF, Holt VL, Martin DP. What do women want to know after child birth? Birth 1997;24: 27-34.

37. Snelson W, Mason L, Hewitt K. Primiparity and maternal perceptions. Health Visitor 1990;12:409-10.

38. Little CM, Lewis JA. Newborn Screening. Newborn\& Infant Nursing Reviews 2008; 8:3-9.

39. Gürel SA, Gürel H, Balcan E. Doğum öncesi bakım esnasında gebelik, doğum ve doğum sonu döneme ilișkin bilgi edinme durumu. Perinatoloji Dergisi 2006; 14:90-5. 